\title{
Triumph Over Thalassemia-Universal Wakefulness
}

\section{Safila Naveed ${ }^{1 \star}$, Syeda Sarah Abbas ${ }^{1,2}$, Fatima Qamar ${ }^{1}$ and Zohra Barket Ali}

${ }^{1}$ Jinnah University for Women Karachi, Pakistan

${ }^{2}$ Department of Pharmaceutics, University of Karachi, Pakistan

\begin{abstract}
Thalassemia is a genetic or inherited disorder in which body makes fewer Red blood cells and produce less hemoglobin. This disorder is very common in Mediterranean regions, south and south East Asians. This commentary gives wakefulness to the healthy individuals as well as to those patients who are being suffering from minor thalassemia. The focal purpose to write this critique is to furnish awareness and dwindle down the rate of mortality in Pakistan as well as in Asians and across the Globe.
\end{abstract}

Keywords: Thalassemia; Hemoglobin; Genetic disorder; Pakistan; Asians; Minor thalassemia

\section{Introduction}

Thalassemia is an inherited disorder caused by impaired synthesis of one or more globin chains. It is also called as autosomal recessive gene disorder. The impairment alters production of hemoglobin $(\mathrm{Hb})$. A variety of anemia is caused due to thalassemia which can intimidate to life. People of Mediterranean, Middle Eastern, African, and Southeast Asian descent are at higher risk of carrying the genes for thalassemia (Weatherall). This hereditary disease can cause by mutations that decrease hemoglobin synthesis and red cell survival [1]. Hemoglobin is a heterotetramer protein, compose of two alpha and two beta subunits. Each subunit contains a heme group, an iron containing compound that binds to oxygen. The two developmentally regulated multigene clusters: the alpha-like globin cluster on chromosome 16 and the beta-like globin cluster on chromosome 11 controlled the synthesis of hemoglobin [2,3]. According to which chain of the hemoglobin molecule is affected the thalassemia are classified.

\section{Types of Thalassemia}

There are two main kinds of thalassemia.

I. Alpha thalassemia occurs when a gene or genes related to the alpha globin protein are altered.

II. Beta thalassemia occurs when similar gene defects affect production of the beta globin protein [4-9].

There are some sign and symptoms of thalassemia patients:

\section{Signs and Indications}

- Severe tissue hypoxia

- Hemolytic anemia

- Iron overload

- Shortness of breath

- Bone deformities in the face

- Dark urine Slowed growth and delayed puberty

- Jaundice

- An enlarged spleen, liver, and heart [10]

Blood transfusion therapy is major therapy of thalassemia which is very painful. Bone marrow transplantation (BMT) is expensive and curative. According to new research, $16 \%$ of Pakistani people suffering from thalassemia [11].

\section{Result and Discussion}

Thalassemia is a genetic disorder. A higher incidence of thalassemia is shown in the Mediterranean region, the Asian subcontinent and Southeast Asia. To triumph over this disease the need is to test your blood if the test shown minor thalassemia then according to rule or law. Regular blood transfusions and iron chelation with deferoxamine have changed the diagnosis of the disease. Bone marrow transplantation, so far the only definitive cure for thalassemia, became accessible in 1981 and technological advances continue to be reported. Consequently, trustworthy facts on the prognosis of patients treated conventionally have become of paramount significance in order to create evocative conclusion concerning genetic counseling and option of therapy for children who have an HLA-matched donor [12-14].

Our research group has furthermore done this type of awareness campaign in the form of short reports and communication, commentary and critiques and established the entire in a structure of manuscript. The central chore and confront behind this doing is to craft global awareness among general population on such prevailing issues which are being neglected by our main society and its citizens [15-18].

\section{References}

1. Forget B, Cannelos G, Berlin N (2010) Pediatric Clinics of North America Thalassemia. Saunders WB Company 24

2. Lukens JN (1993) The thalassemias and related disorders: quantitative disorders of hemoglobin synthesis. In: Lee GR (Eds) Wintrobe's Clinical Hematology $9^{\text {th }}($ Edn) Lea \& Febiger, PA Press 1: 1102-1145.

3. Steensma DP, Gibbons RJ, Higgs DR (2005) Acquired alpha-thalassemia in association with myelodysplastic syndrome and other hematologic malignancies. Blood 105: 443-452.

4. Boulad F, Giardina P, Gillio A, Kernan N, Small T, et al. (1998) Bone marrow transplantation for homozygous betathalassemia. The Memorial SloanKettering Cancer Center experience. Ann N Y Acad Sci 850: 498-502.

*Corresponding author: Naveed S, Faculty of Pharmacy, Jinnah University for Women, Karachi, Pakistan, Tel: 00923002621917; E-mail: safila117@yahoo.com

Received October 27, 2015; Accepted February 01, 2016; Published February 08, 2016

Citation: Naveed S, Abbas SS, Qamar F, Ali ZB (2016) Triumph Over ThalassemiaUniversal Wakefulness. J Bioequiv Availab 8: 106-107. doi:10.4172/jbb.1000277

Copyright: $\odot 2016$ Naveed S, et al. This is an open-access article distributed under the terms of the Creative Commons Attribution License, which permits unrestricted use, distribution, and reproduction in any medium, provided the original author and source are credited. 
Citation: Naveed S, Abbas SS, Qamar F, Ali ZB (2016) Triumph Over Thalassemia-Universal Wakefulness. J Bioequiv Availab 8: 106-107. doi:10.4172/ jbb.1000277

5. Borgna-Pignatti $\mathrm{C}$ (2007) Modern treatment of thalassaemia intermedia. $\mathrm{Br} \mathrm{J}$ Haematol 138: 291-304.

6. Agarwal MB (2004) Advances in management of thalassemia. Indian Pediatr 41: $989-992$

7. Moi $P$, Sadelain M (2008) Towards the genetic treatment of beta-thalassemia: new disease models, new vectors, new cells. Haematologica 93: 325-330.

8. Raja JV, Rachchh MA, Gokani RH (2012) Recent advances in gene therapy for thalassemia. J Pharm Bioallied Sci 4: 194-201.

9. Sadelain M, Wang CH, Antoniou M, Grosveld F, Mulligan RC (1995) Generation of a high-titer retroviral vector capable of expressing high levels of the human beta-globin gene. Proc Natl Acad Sci U S A 92: 6728-6732.

10. Jetawattana S (2005) Thalassemias, disorders of hemoglobin. Free Radicals in Biology and Medicine 77: 1-23.

11. Durga Devi NK, Sai Sree M, Abhinaya M (2012) Screening, analysis techniques and treatment strategies for haemoglobin $E$ beta-thalassemia. Int $J$ Drug Res Tech 2: 472-478.

12. Thomas ED, Buckner CD, Sanders JE, Papayannopoulou T, Borgna-Pignatti C, et al. (1982) Marrow transplantation for thalassaemia. Lancet 2: 227-229.
13. Locatelli F, Rocha V, Reed W, Bernaudin F, Ertem M, et al. (2003) Related umbilical cord blood transplantation in patients with thalassemia and sickle cell disease. Blood 101: 2137-2143.

14. Borgna-Pignatti C, Rugolotto S, De Stefano P, Zhao H, Cappellini MD, et al. (2004) Survival and complications in patients with thalassemia major treated with transfusion and deferoxamine. Haematologica 89: 1187-1193.

15. Abbas SS, Naveed S, Qamar F, Zainab S, Jawed SH, et al. (2015) Autism spectrum disorder (ASD); A threat to social communication. World Journal of Pharmaceutical and life Sciences 1: 203-205.

16. Naveed S, Abbas SS, Qamar F, Ali ZB , Kiran S, et al. (2015) Textaphrenia; Turmoil For Adults, World Journal of Pharmaceutical and life Sciences 1: 70-72.

17. Naveed S, Sana A, Rehman H, Qamar F, Abbas SS, et al. (2015) Prevalence and Consequences of PHOBIAS, Survey Based Study in Karachi. J Bioequiv Availab 7: 140-143.

18. Abbas SS, Qamar F, Naveed S (2015) Pharmacy: A Dignified Profession but yet Deserted; A Dilemma for Pharmacy Profession and Future Pharmacist. J Bioequiv Availab 7: e65. 